\title{
E-Banking as a Tool for Competition Advantage in Albania
}

Prof. Assoc. Evelina Bazini

Faculty of Economy, University of Vlora "Ismail Qemali", Albania

evelina. bazini@univlora.edu. al

\begin{abstract}
The adoption of e-banking is occurring quite extensively as a channel of distribution for financial services due to rapid advances in ICT and intensive competitive banking markets. E-banking offers o lot of benefits which add value to customers' satisfaction in terms of better quality of service offerings and at the same time enable the banks gain more competitive advantage over other competitors. Internet banking is either offered as a value added service of physical bank branches or a virtual bank where customers can only perform banking transactions through the Internet and it is important to mention that operating costs of a virtual bank are much lower compared to traditional banks. This study is designed to evaluate e-banking as a strategy and related methods adopted in banking sector in Albania to improve the customer satisfaction. The aim was to analyze customers' perception towards e-banking services, the quality of e-banking services provided by the banks and the constraints in achieving customer satisfaction. The study also recommends the possible and practical additional measures the banks should take in order to achieve maximum customer satisfaction. Data were collected from the bank customers through self designed structured questionnaires. Out of 100 questionnaires distributed, only $62 \%$ were returned/ responded back. Non-probability sampling was used due to the limitation of resources and time. Data management and analyses were done using SPSS program and Microsoft excel.
\end{abstract}

Keywords: e-banking, competitive advantage, customers satisfaction, e-distribution channels.

\section{Introduction}

E-banking allows customers of a financial institution to conduct financial transactions on a secure website operated by the institution, which can be a retail or virtual bank, credit union or building society. Electronic or online banking is the latest delivery channel to be presented by the retail banks and there is large customer acceptance rate which means delivery of banking services to customers using electronic technology either at their office or home.

The E-Banking offers enormous opportunities in every sphere of business as the competitive advantage, member/ client retention increased revenues and reduced costs.

\section{Literature review}

\section{1. Definition of e-banking}

Daniel (1999) described electronic banking as the provision of banking services to customers through Internet technology. Other authors (Daniel, 1999; Karjaluoto et al. , 2002) indicated that banks have the choice to offer their banking services through various electronic distribution channels technologies such as Internet technology, video banking technology, telephone banking technology, and WAP technology. Karjaluoto et al. (2002) also indicated that Internet technology is the main electronic distribution channel in the banking industry. In more detail the author described e- banking as an online banking that involves the provision of banking services such as accessing accounts, transferring funds between accounts, and offering an online financial service.

E-banking is also called as "Virtual Banking" or "Online Banking". E-banking is a result of the growing expectations of bank's customers. E-banking involves information technology based banking. Under this I. T system, the banking services are delivered by way of a Computer-Controlled System. This system does involve direct interface with the customers. The 
customers do not have to visit the bank's premises. Popular services covered under E-Banking. The popular services covered under E-banking include:

- $\quad$ Automated Teller Machines

- $\quad$ Credit Cards

- $\quad$ Debit Cards

- Smart Cards

- $\quad$ Electronic Funds Transfer (EFT) System,

- Cheques Truncation Payment System

- Mobile Banking, Internet Banking

- Telephone Banking, etc.

\subsection{Competitive Advantage - a conceptual framework}

The concept of competitive advantage used by Porter (Porter's work - 1979, 1980, 1985, and 1990), is still the starting point for any discussion of competitive advantages even thought there are many economists who used the concept of competitive advantage before him (Jones 2003). Straub and Klein (2001) and Barney (2002) argue that the term of competitive advantage did not appear in Porter's work until the year 1985, whereas Caves (1984), Day (1984), Spence (1984) and Barney (1986) used the term around the same times as Porter while Penrose (1959) and Ansoff (1965) used the concept of competitive advantage before that time.

Competitive advantage is recognized as a continuous concern for all companies. According to Dussauge et al (1992) technology could be considered as the core element that enables the company to identify the two major generic strategies: cost leadership and differentiation. Porter defined competitive advantage as the heart of a company's performance and it's reflects companies' ability to offer consumers greater value, either by means of lower prices or by providing greater benefits and services that justifies higher prices (Porter, 2000). Order-winning criteria include rate of innovation, fitness for purpose, volume flexibility, variety, extreme customization and, above all, rapid responsiveness (Berawi, 2004; Porter, 2000). In addition, companies can create competitive advantage by achieving or discovering new and better ways to compete in an industry and taking them to the market, which is ultimately an act of innovation (Abdul-Rahman \& Berawi, 2002; Porter 2000). Moreover, Porter (2000) stated that, recently, companies try to build up distinctive strategies that result in realistic profitability. Thus, he recommended a continuous development in products and in approaches to competing by the innovative use of technology. Strategic innovation is considered as the basis for competitive advantage (Grant, 2005); it is recognized as a source of competitive advantage (Porter, 1980).

When two or more firms compete within the same market, one firm possesses a competitive advantage over its rivals when it earns or has the potential to earn a persistently higher rate of profit (Porter, 1980; Grant, 1997; Hill et. al, 2001). Competitive advantage then is the ability of the firm to occupy a superior position in an industry and outperform its rivals on the primary performance goal- profitability. A company's superior competitive position allows it to achieve higher profitability than the industry's average (Porter, 1985). Competitive advantage can arise from various sources. According to Porter (1985), a firm can achieve a higher rate of profit (or potential profit) over a rival in one of two ways: either it supplies an identical product or service at a lower cost, in which case the firm possesses a cost advantage; or it can supply a product or service that is differentiated in such a way that the customer is being able to pay a price premium that exceeds the additional cost of the differentiation advantage.

\subsection{The advantages of e-banking ${ }^{8}$}

E-banking has recently come to be considered as one of the most effective banking transaction methods because it possesses many advantages which offline banking channels cannot offer. E-banking managers aim to utilize these advantages to increase the online banking adoption rate.

Based to a certain extent on reasons offered by Lee, there are two main types of perceived benefits, which can be categorized as direct and indirect advantages. Direct advantages refer to immediate and tangible benefits that customers 
would enjoy by using online banking. For example, customers can benefit from series of services, as a wider range of financial benefits, faster transaction speed, and increased information transparency.

First, this wider range of financial benefits includes the lower transaction handling fees, higher deposit rates, opportunities to win prizes and extra credit card bonus points.

Second, the faster transaction speed obviously means that time can be saved since online banking does not need paper documents, the processing of which can give rise to errors and delays, and which also requires more personnel. Online banking automates this process by mediating transactions through websites and electronic data interchange, and can also reduce the need for customers to communicate with bank staff regarding transaction details because these can be obtained from a website.

Third, during the transaction, online banking allows customers to monitor contractual performance at any time, or to confirm delivery automatically. In other words, more relevant information is immediately available and transparent to customers.

Indirect advantages are those benefits that are more intangible and difficult to measure. For example, online banking allows customer to perform banking transactions anywhere in the world and enjoy 24-hour service, as well as offering customers more investment opportunities and services, such as stock quotations and news updates.

Another classification for the benefits of e-banking is that based on from the viewpoint of customers, banking organizations and economy in general. IT as an enabler has broken all bounds of cost, distance and time.

\section{Current situation of using e-banking in Albanian banking sector}

In the Albanian banking sector today operate 16 banks, with fully private capital and foreign capital dominates. The number of banks began to increase after the ' 90 , when in 1992, 4 new banks were licensed. And over the years, banking sector in Albania, began to improve, thus increasing the number of banks that compete in this market, which definitely brought the increase of influence of this sector in economic development, through increased funding to individuals and firms in the economy.

This can be considered as a relatively large number of banks compare with the number of population in Albania, which increases the competition and makes it difficult the cooperation between banks to increase the interest rate. However if we compare our banking system with other relional countries, in Albanian banking system operates the smaller number of banks ${ }^{11}$.

In Albania, electronic services became part of the banking system much later compared to developed countries. Security of transactions has been one of the main problem that has accompanied the performance of electronic services in developed countries. Over time banks gained experience while minimizing some of the problems previously encountered. In Albania, the range of products that commercial banks have added as electronic products and services has increased over the years. As in the world, even in Albania they were initially foreign banks who first introduced electronic services. Later, even local banks agreed to offer their products electronically. The facts show that electronic services are in their infancy. The main reason lies in the cost-benefit ratio. If there is a significant number of clients that will use e-banking as a service then the high costs associated with providing this service would cause losses for banks. Electronic banking is actually associated with both the traditional channels (like counters and affiliates) and also automatic channels (ATM and POS). Multi-channel tracking strategy is aimed to strengthen client-bank relationship day after day. Supervision Report of 2006 showed that electronic products and services used by commercial banks in customer service were adopted as the provision of ATM services, electronic cards of almost all banks by increasing the speed and quality of service (Surveillanc Report , 2006) $)^{11}$.

The first bank that has provided e-banking is the American Bank of Albania in 2002, with the introduction of ABAflex. It remains the only bank that offers a package of services inherent in the Internet. Efforts by other banks to offer e-banking service were made by other banks such as for example the Raiffeisen Bank, National Bank, Credins etc. (BoA, 2007: 28). Today, among 16 banks that contain banking system in our country, only nine of them offer electronic services ${ }^{11}$. 


\section{Research methodology}

This study is designed to evaluate e-banking as a strategy and related methods adopted in banking sector in Albania to improve the customer satisfaction. The aim was to analyze customers' perception towards e-banking services, the quality of e-banking services provided by the banks and the constraints in achieving customer satisfaction. The study also recommends the possible and practical additional measures the banks should take in order to achieve maximum customer satisfaction.

Data were collected from the bank customers through self designed structured questionnaires. Out of 100 questionnaires distributed, only $62 \%$ were returned/ responded back. Non-probability sampling was used due to the limitation of resources and time. Data management and analyses were done using SPSS program and Microsoft excel.

\section{Research results}

Out of 100 questionnaires distributed, only $62 \%$ were returned/ responded back. Out of 62 questionnaires collected, about $71 \%$ were female and $29 \%$ were male. Besides, $92 \%$ of samples hold bachelors or higher university degree. In terms of occupation about $87 \%$ of them were found engaged in the private sector $13 \%$ of the respondents were engaged in the public sector. Around $93 \%$ of the respondents in our sample have heard about the e-banking, out of which around $87 \%$ were the female respondents. Among those who have not heard about the e-banking most of them were the housewives (62. 3\%). About the source of respondents' knowledge about e-banking, $93 \%$ who have heard about the e-banking, $32 \%$ have heard from the media (television, radio, or newspaper), and $41 \%$ have got the information from the bank itself. Similarly, $27 \%$ of the respondents have got the information from other users of e-banking.

Out of 62 respondents under surveyed, $82 \%$ indicated they do e-banking service with their banks compare to $25 \%$ that do not. Only $17 \%$ of them preferred the face to face or conventional banking. This means that $83 \%$ prefer e-banking to the traditional banking system. The major types of e-banking services enjoyed by the customers in the following order are ATM banking (76\%); Money Transfer (83\%); and all Internet banking facilities (12\%). The reasons given by the respondents for preferring e-banking to traditional banking practice include: availability of banking facility anytime and anywhere; it is easy to use; time saving; it offers a convenient way of operating banking transactions; there is no need for queuing. A greater proportion $(87 \%)$ of the respondents is very comfortable with the e banking choice while only very few of them are not comfortable (13\%). The reasons given by the respondents that are not comfortable are: security concern, lack of knowledge, unreliability and preference for face to face contact. The most part of the them who use e-banking hold bachelors, higher university degrees or were representatives of private businesses that operate in the area or employ of public agencies. For the two last categories this was not a new practice since they use internet services for other reasons at their businesses or agencies. This helps to understand the fact that greater proportion (82\%) of the respondents do e-banking themselves while $18 \%$ sort help when doing e-banking. There are $78 \%$ respondents that indicated they were satisfied with the ebanking services provided by their banks while $22 \%$ are not satisfied. The reasons given by those respondents who are satisfied include: easy access, customer friendly environment, faster than conventional banking that mean no long lines for making money transfers, using your account anytime and anywhere, even when they are abroad, and assistant from bank employs any time. Those respondents not satisfied with the e-banking services gave the following reasons: slow response of Internet connection and inaccessibility.

When asked for the benefits of using e-banking, the respondents gave the following list: speedy transfer; efficient transactions; regular check of transaction and statement details, easy access; saves transaction costs; lower transaction fees. The expected associated risks of e-banking identified by the respondents from the study are: cyber fraud; cyber theft; security concerns; risk of hackers; leaked customer information; making closed system open up; third party intervention ; transaction process and wrong information/code from sender and others such as card retrieval problem, delay due to wrong codes, unreliable power supply, slow Internet connectivity, system failure/error and lack of knowledge. When asked whether or not customers' bank choice is influenced by the quality of e-banking services and/or products provided, the majority of the respondent in all the five banks included in the research were answered that they are satisfied with the e-banking services. Only in two of the banks, customers were very satisfied with the facilities and assistants provided by the banks employers in using e-banking. This trend if sustained, may give to these two banks a competitive advantage over others in the nearest future. 


\section{Concluding remarks}

A competitive advantage is an advantage gained over competitors by offering customers greater value, either through lower prices or by providing additional benefits and service that justify similar, or possibly higher, prices.

This study attempts to examine whether customers' choice of banks is influenced by the quality of e-banking services and products provided. In Albania, electronic services became part of the banking system much later compared to developed countries. Security of transactions has been one of the main problem that has accompanied the performance of electronic services in developed countries. Over time banks gained experience while minimizing some of the problems previously encountered. Banks should drown themselves in all the intricacies regarding e-banking to determine ways that will affect the customers satisfaction and use it to their maximum benefit. The salient dimensions of marketing orientation which are customer and competitor orientation, are considered important strategic orientations to achieve a competitive advantage (Sørensen, 2009; Zhou et al. , 2005; Slater and Narver, 1994; Day and Wensley, 1988; Day and Wensley, 1983).

\section{References}

[1] Basheer Abbas Al-alak, Saeed (M. Z) A. Tarabieh., Gaining competitive advantage and organizational performance through customer orientation, innovation differentiation and market differentiation. International Journal of Economics and Management Sciences, Vol. 1, No. 5, 2011, pp. 80-91.

[2] Bashi. E. , The Advantages of E-Banking in the Albanian Banking Sector (Case of Shkodra). European Academic Research Vol. I, Issue 12/ March 2014. Impact Factor: 3. 1 (UIF). DRJI Value: 5. 9 (B+). ISSN 2286-4822 www. euacademic. org.

[3] Calabrese A, Costa R, Menichini, T (2013) Using Fuzzy AHP to manage Intellectual Capital assets: an application to the ICT service industry. Expert Systems With Applications 40 (9): 3747-3755.

[4] Calabrese A, Scoglio F (2012) Reframing the past: A new approach in service quality assessment. Total Quality Management \& Business Excellence. 23 (11-12): 1329-1343.

[5] Capece. G. , Campisi. D. A Behavioral Model of E-Banking Usage in Italy. Int. j. eng. bus. manag. , 2013, Vol. 5, 16:2013. www. intechopen. com.

[6] Carignani. A. , Seifert. F. , Competitive Advantage, Online Brokerage and IT: evidence from Italian and German companies.

[7] Costa, R (2012) Assessing Intellectual Capital efficiency and productivity: an application to the Italian yacht manufacturing sector. Expert Systems With Applications. 39 (8): 7255-7261.

[8] Guendalina Capece1, * and Domenico Campisi1 - A Behavioural Model of E-Banking Usage in Italy. International Journal of Engineering Business Management.

[9] Huang S-M, Hung Y-C, Yen DC (2005) A study on decision factors in adopting an online stock trading system by brokers in Taiwan. Decis Support Syst 40 (2): 315-28.

[10] K. Saranya, K. S. Gunasri. "Challenges in E-Banking", International Journal of scientific research and management (IJSRM), Special Issue On e-Marketing Road Ahead Of India, Pages, 22. 27. 2013. Website: www. ijsrm. in ISSN (e): 2321-3418

[11] Kripa. E. , Seita. M. , Factors influencing the usage of e-banking service by individuals. European Academic Research Vol. III, Issue 2/ May 2015. Impact Factor: 3. 4546 (UIF) DRJI Value: 5. 9 (B+). ISSN 2286-4822. www. euacademic. org.

[12] Lee M-C (2008) Predicting behavioral intention to use online banking. In: Proceedings of the 19th International Conference on Information Management, Taiwan. 
[13] Matraku. D. , Gjoka. E. , Competition in Albanian banking sector. International Journal of Business and Management Vol. II (1), 2014

[14] Matraku. D. , Gjoka. E. , Competition in Albanian banking sector. International Journal of Business and Management Vol. II (1), 2014.

[15] Megha Arunkumar Jain, G. H Barhate - A Study on Emerging Opportunities \& Challenges Towards E-Banking System in India. - international Journal of scientific research. Volume : 3 | Issue : 9 | September $2014 \cdot$ ISSN No $2277-8179$.

[16] Megha Arunkumar Jain, G. H Barhate. "A Study on Emerging Opportunities \& Challenges Towards E-Banking System in India", International Journal of scientific research. Volume: 3, Issue: 9, September 2014. ISSN No 2277 8179.

[17] Momeni. M. , Kheiry. B. , Dashtipou. M. , Analysis the effects of Electronic Banking on Customer Satisfaction and Loyalty (Case study: Selected Branches of Melli Bank in Tehran). Interdisiplinary journal of contemporary research in business. Aprile 2013, Vol. 4, No. 12. ijcrb. webs. com.

[18] Naqellari. A. , Pacukaj. S. , Shahini. E. , Development Of The Banking Market In Albania. European Journal of Sustainable Development (2014), 3, 3, 329-344 ISSN: 2239-5938.

[19] Omari. H. , Bataineh. T. , The Impact of e-Banking on Achieving Competitive Advantage for Banks in Jordan. Interdisciplinary journal of contemporary research in business. November 2012, Vol. 4. No. 7.

[20] Salim Al-Hajri. International Review of Business Research Papers Vol. 4 No. 5 October-November 2008 Pp. 120-128

[21] Salim Al-Hajri. The Adoption of e-Banking: The Case of Omani Banks. International Review of Business Research Papers. Vol. 4 No. 5 October-November 2008 Pp. 120-128

[22] Shingjergji. A. , Shingjergji. A. Analysis of the Albanian Banking System in the Transition Years. International Journal of Business and Commerce Vol. 2, No. 4: Dec 2012[78-89] (ISSN: 2225-2436). www. ijbcnet. com.

[23] Spaho. A. , Ramaj. T. , Electronic banking usage in Albani: A statistical analysis. IMPACT: International Journal of Research in Business Management (IMPACT: IJRBM). ISSN (E): 2321-886X; ISSN (P): 2347-4572 Vol. 2, Issue 12, Dec 2014, 1-10. @ Impact Journals.

[24] Vadinaj. E. , E-banking - The main perspective in developing the financial system in Albania. Economics Questions, Issues and Problems, ISBN 978-80-89691-07-4.

[25] R. A. Gbadeyan, O. O. Akinyosoye - Gbonda. Customers' preserences for e-banking services: A case study of selected banks in Siera Leone. Australian Journal of Business and Management Research Vol. 1, No. 4, pg. 108116. July-2011. 